\title{
Effect of rhizospheric nutrient management on root growth, yield, and nutrient use efficiency of wheat (Triticum aestivum L.) under Tarai region of Uttarakhand, India
}

\author{
Arvind Kumar* \\ Department of Agronomy, G.B. Pant University of Agriculture \& Technology, Pantnagar, US \\ Nagar-263145 (Uttarakhand), India \\ Vijay Pal Singh \\ Department of Agronomy, G.B. Pant University of Agriculture \& Technology, Pantnagar, US \\ Nagar-263145 (Uttarakhand), India \\ Rajeew Kumar \\ Department of Agronomy, G.B. Pant University of Agriculture \& Technology, Pantnagar, US \\ Nagar-263145 (Uttarakhand), India

\section{S. Pandey} \\ Department of Agronomy, G.B. Pant University of Agriculture \& Technology, Pantnagar, US \\ Nagar-263145 (Uttarakhand), India

\section{V.K. Singh} \\ Department of Agronomy, G.B. Pant University of Agriculture \& Technology, Pantnagar, US \\ Nagar-263145 (Uttarakhand), India \\ *Corresponding author. E mail: arvindbishnoi29e@gmail.com
}

\section{Article Info}

https://doi.org/10.31018/ jans.v12i4.2362

Received: August 28, 2020

Revised: November 6, 2020

Accepted: November 17, 2020

\section{How to Cite}

Kumar A. et al. (2020). Effect of rhizospheric nutrient management on root growth, yield, and nutrient use efficiency of wheat (Triticum aestivum L.) under Tarai region of Uttarakhand, India. Journal of Applied and Natural Science, $12(4)$ : 511 - 518. https://doi.org/10.31018/jans.v12i4.2362

\begin{abstract}
Rhizospheric nutrient management and fertilizer placement can be a useful measure to improve wheat crops productivity in Tarai regions of India. An experiment was conducted to evaluate the effects of rhizospheric nutrient management on wheat (Triticum aestivum L.) to explore the relationship between root proliferation, grain yield and NUE in Tarai region of Uttarakhand, India. It comprised 3 fertilizer application (P1 to P3) and 6 nutrient management treatments (T1 to T6) with absolute control in a randomized complete block design and replicated thrice. Experimental results indicated that P1 $(1.29$ and $1.47 ; 1.84$ and 2.29 $\mathrm{mg} / \mathrm{cc}$ ) produced greater root density, and compared to P3 (1.39 and 1.49; 1.74 and $2.17 \mathrm{mg} / \mathrm{cc}), \mathrm{P} 2$ (1.24 and $1.36 ; 1.68$ and $1.97 \mathrm{mg} / \mathrm{cc})$ and absolute control $(0.85$ and $1.19 ; 1.42$ and $1.69 \mathrm{mg} / \mathrm{cc})$ at maximum tillering and flowering stage in year $2017-18$ and 2018-19, respectively. The root proliferation also influenced the grain yield (5.4 and 5.5; 5.3 and 5.3; 5.1 and 5.2; 3.5 and $3.3 \mathrm{t} / \mathrm{ha}$ ) in P1, P3, P2 and absolute control in the year 2017-18 and 2018-19, respectively. However, the grain yield and root distributions (at the flowering stage) recorded significantly $(p=0.05)$ maximum in T4 (5.8 and $5.7 \mathrm{t} / \mathrm{ha} ; 1.84 \mathrm{and} 2.32 \mathrm{mg} / \mathrm{cc}$ ) followed by T3, T6, T1, T5, T2 treatments and minimum in absolute control ( 3.5 and3.3 t/ha; 1.42 and $1.69 \mathrm{mg} / \mathrm{cc})$ in the year of 2017-18 and 2018-19, respectively. Thus, the rhizospheric nutrient management (75\% RDF+ vermicompost + PSB) with fertilizer placement can be a feasible approach for increasing grain yield and NUE in Tarai regions of Uttarakhand, by promoting deep root development and reducing fertilizer inputs in wheat.
\end{abstract}

Keywords: Grain yield, Nutrient use efficiency, Rhizospheric nutrient management, Root growth, Triticum aestivum L., Wheat

\section{INTRODUCTION}

Wheat (Triticum aestivum L.), is the most important staple food crop after rice which triggered the green revolution in the Indian subcontinent. Globally, Billion of people depends on wheat for a substantial part of their diet. The nutritional importance of wheat protein should not be underestimated, particularly in a developing country like India (Kumar et al., 2011). Globally, wheat was cultivated over an area of 222.7 mha with production is $742.1 \mathrm{mt}$ and productivity of $3.33 \mathrm{t} / \mathrm{ha}$ (FAO, 2017). India stands second among wheatproducing countries in terms of area and production. In India, wheat was grown over an area of 30.2 mha with a production of $97.44 \mathrm{mt}$ and a productivity of $3.09 \mathrm{t} / \mathrm{ha}$ (GOI, 2016). Uttarakhand consists of hilly tracts as well as TarailPlains areas where wheat is grown as a rabi crop. Overall, the state has occupied the area of 0.34 mha which produced $0.76 \mathrm{mt}$ of wheat during 2012-2013 with a productivity of $2.22 \mathrm{t} /$ 
ha (GOI, 2016).

The population growth, overuse of chemical inputs and reduction in agricultural land are placing divesting pressure on Indian agriculture and natural resources for satisfying the increasing food demand (Foley et al., 2011). Both food production and soil fertility can be improved with the efficient supply of soil nutrients (Mi et al., 2010 and Zhang et al., 2010). The high yielding varieties and excessive use of chemical fertilizers shrink the soil production capacity (Fan et al., 2012). So, efficient inputs management is the prime necessity for improving soil health and wheat ( $T$. aestivum L.) productivity which can be possible through exploiting the rhizospheric potential of soil by carbon management/ carbon degradation. The soil bio-geophysical properties and root proliferation with the acceleration of agronomic practices (Cultivation, Residue management, localized fertilizer applications and fertilization regulate microbial activities). All these activities regulated the soil nutrient cycling, mobilization, and uptake by plants (Marschner, 2012). The development of roots and rhizospheric system are much efficient when it is empowered with fertilizer placement and timing that fulfils aim to intensify the root-soil nutrient pool. Therefore, the different fertilizer application methods viz., Broadcasting, Band placement, and Deep placement are used to accelerate the better root- nutrient contact. Various studies of last decades suggested that the fertilizer placement helps us to short out the nutrient losses from the soil, direct contact of fertilizer with seed and ensure better nutrient availability to plant roots (Nkebiwe et al., 2016). However, the other study conducted on major nutrient application showed that combined use of NPK fertilizers with the localized application have a positive response to wheat $T$. aestivum productivity and soil quality due to better root development and improved nutrient uptake. In this endeavour, conjoint use of organic and inorganic fertilizers with biostimulants are effective either for increasing yield or sustaining soil health (Weber et al., 2008; Pullicinoa et al., 2009; Aggarwal et al., 2003 and Bhatt et al., 2016). The microbial inoculants and organic manure are applied along with the reduced level of fertilizer to enhance the crop growth and yield (Kumar et al., 2019 and Mengual et al., 2014). Therefore, Better soil, crop and nutrient management practices play a pivotal role to achieve the goal of improving soil health and nutrient use efficiency of wheat. It should be narrow down the yield gap between achievable and actual yields of wheat.

So, a judicious combination of organic manures and bio-fertilizers as a carbon source with chemical fertilizers placed into the rhizosphere facilitates profitable and sustainable wheat production. The responses of the organic sources of nutrients are variable with location and soil fertility status. So, the analyses of various field studies on fertilizer sources and placement raised an important question that "which fertilizer source and placement can be chosen for improving wheat productivity and soil health?" Rhizospheric nutrient management provides a unique opportunity to improving crop productivity and soil health along with the reduction of environmental pollutions. Therefore, this study was focused on: 1) to determine the effectiveness of rhizospheric nutrient management options to improving wheat $T$. aestivum grain yield by manipulating the rhizospheric environment; 2) to improve our understanding of efficient fertilizer placement for wheat; 3 ) to assess the variation in root traits and the rhizospheric environment with relationship to yield in wheat; and 4) to assess the effectiveness of fertilizer placement and rhizospheric nutrient management options for improving nutrient use efficiency of wheat in Pantnagar, Tarai region of Uttarakhand .

\section{MATERIALS AND METHODS}

Site description: The field experiment was performed from 2017-18 to 2018-19 at the D-3 block of Norman E. Borlaug Crop Research Centre of G.B. Pant University of Agriculture and Technology, Pantnagar, Distt. Udham Singh Nagar $\left(29^{\circ} \mathrm{N}\right.$ latitude and $79.3^{\circ} \mathrm{E}$ longitudes, 243.84 m A.M.S.L.) in Uttarakhand, India. The experimental soil is aquic hapludoll, and comprise $32 \%$ sand, $39 \%$ silt, and $29 \%$ clay (Deshpande et al. 1971). The soils typically had a $\mathrm{pH}$ of 7.4 and a bulk density of $1.3 \mathrm{~g} \mathrm{~cm}-3$. Analyses of soil at the experimental field prior to planting in 2017-18 indicated that the top $20 \mathrm{~cm}$ contained $0.77 \%$ organic matter, $21.6 \mathrm{~kg} / \mathrm{ha}$ available phosphorus, $189 \mathrm{~kg} / \mathrm{ha}$ available potassium, and $296 \mathrm{~kg} / \mathrm{ha}$ total nitrogen. The dominant crop production system in this region was based on conventional tilling and rice (Oryzae sativa)-wheat ( $T$. aestivum L.) cropping system. The annual average rainfall amounts at Pantnagar station is 1421.8 and 1572.2 mm during 2017-18 and 2018-19, respectively of which approximately $80-90 \%$ was during the June to October each year ( Fig. 1 and 2).

Experimental design and treatments: The wheat $(T$. aestivum L.) cultivars were subjected to six rhizospheric nutrient management treatments, in triplicate, using a randomized complete block design with 57 plots in total, each covering $13.14 \mathrm{~m}^{2}(7.30 \mathrm{~m} \times 1.80 \mathrm{~m})$. The six rhizospheric nutrient management treatments [100\% RDF (150:60:40 kg/ha NPK) (T1), 75\% RDF (T2), 75\% RDF+ vermicompost (2q/ha) (T3), 75\% RDF+ vermicompost $(2 \mathrm{q} / \mathrm{ha})+$ PSB (10 kg/ha)(T4), $75 \%$ RDF+ Poultry manure (2q/ha) (T5) and $75 \%$ RDF+ Poultry manure (2q/ha) + PSB (10 kg/ha) (T6)] were applied underlying the deep placement (P1), surface application (P2), band placement (P3) and an absolute control. In each plot of the experiment, different nutrient management was applied by a different combination of inorganic, organic and biofertilizers. Fertilizer placement was done according to Fig. 3. In the surface application treatment, the fertilizer was surface broadcast and then ploughed into the soil. In 
the deep placement treatment, the fertilizer mix was applied in seed row at a depth of $12-14 \mathrm{~cm}$, and then seed placed in the same row above the fertilizer mix. In the band placement treatment, $\mathrm{P}$ was furrowed in 3$5 \mathrm{~cm}$ below the soil surface, in 20-cm-wide rows (between rows). The recommended dose of fertilizers was kept 150:60:40 kg/ha NPK. Wheat (Triticum aestivum L.)seed was placed in $20 \mathrm{~cm}$-wide rows at a seeding rate of $100 \mathrm{~kg} \mathrm{ha}^{-1}(\mathrm{WH}-1105)$ on 25 September 2017 and 29 September 2018, respectively.

Sampling procedures and measurements: Root samples were collected from soil samples taken from each plot at 2 stages of growth at jointing and booting. Root studied was done to know the response of rhizospheric nutrient management on root growth. Root weight $(\mathrm{g})$ and root density $\left(\mathrm{g} / \mathrm{cm}^{3}\right)$ was measured at the time of maximum tillering stage and at the flowering stage during each year of experimentation. The root sampler of $15 \mathrm{~cm}$ in height and $10 \mathrm{~cm}$ in diameter was used to volumetric measurement of root volume. Firstly the plants from the target area were cut and core was hammered into the soil. Then, it was removed along with soil. The soil along with roots was transferred to a nylon net bag. It was washed under a water jet to remove soil and separate out the roots. The roots were oven-dried and weighed. The root density was reported in $\mathrm{mg} / \mathrm{cc}$.

Root weight : Wheat ( $T$. aestivum ) roots were collected from two randomly selected rows by root sampler with soil-root mass, washed and weighted. The root weight averaged for root weight in grams.

Root density: Root density was obtained by dividing the root weight $(\mathrm{g})$ from the volume of root sampler $\left(\mathrm{cm}^{3}\right)$. Following formula was used for root density $\left(\mathrm{mg} / \mathrm{cm}^{3}\right)$.
Root density $\left(\mathrm{g} / \mathrm{cm}^{3}\right)=$ Root weight $(\mathrm{g})$
Volume of root sampler $\left(\pi r^{2} h\right)$
Eq........

Where, $\pi, r$ and $h$ were having the value of 3.14 , radius $r(5 \mathrm{~cm})$ and height $h(15 \mathrm{~cm})$, respectively.

Grain yield (t/ha): Crop was harvested from each plot in April 2018 and April 2019 for measurements of grain yield (t/ha).

Calculations and statistical analyses: The data obtained from various observations was statistically analyzed as per the procedure of factorial randomized block design using the standard techniques of Analysis of Variance (ANOVA) as per the procedures given by Rangaswamy (2005). The critical difference at $5 \%$ level of probability was calculated for testing the significance of the difference between any two means wherever ' $F$ ' test was found significant. One sample of absolute control was taken from each net plot. Thus, a total of three samples of absolute control was compared with differential fertilizer placement with and without carbon management separately using ' $F$ ' test as per the method given by Rangaswamy (2005). Wherever the calculated 'F-value' exceeded the tabulated value $(2.028)$, the difference between the treatments was significant.

\section{RESULTS}

Grain yield (t/ha): Fertilizer placement methods influenced the wheat grain yield significantly during 2017-18 and 2018-19 (Table 1). In fertilizer placement methods, $\mathrm{P} 1$ (5.4 and $5.5 \mathrm{t} / \mathrm{ha}$ ) recorded the maximum grain yield and significantly higher over P2 (5.1 and $5.2 \mathrm{t} / \mathrm{ha}$ ) and P3 (5.3 and 5.3 t/ha) during 2017-18 and 2018-19, re-

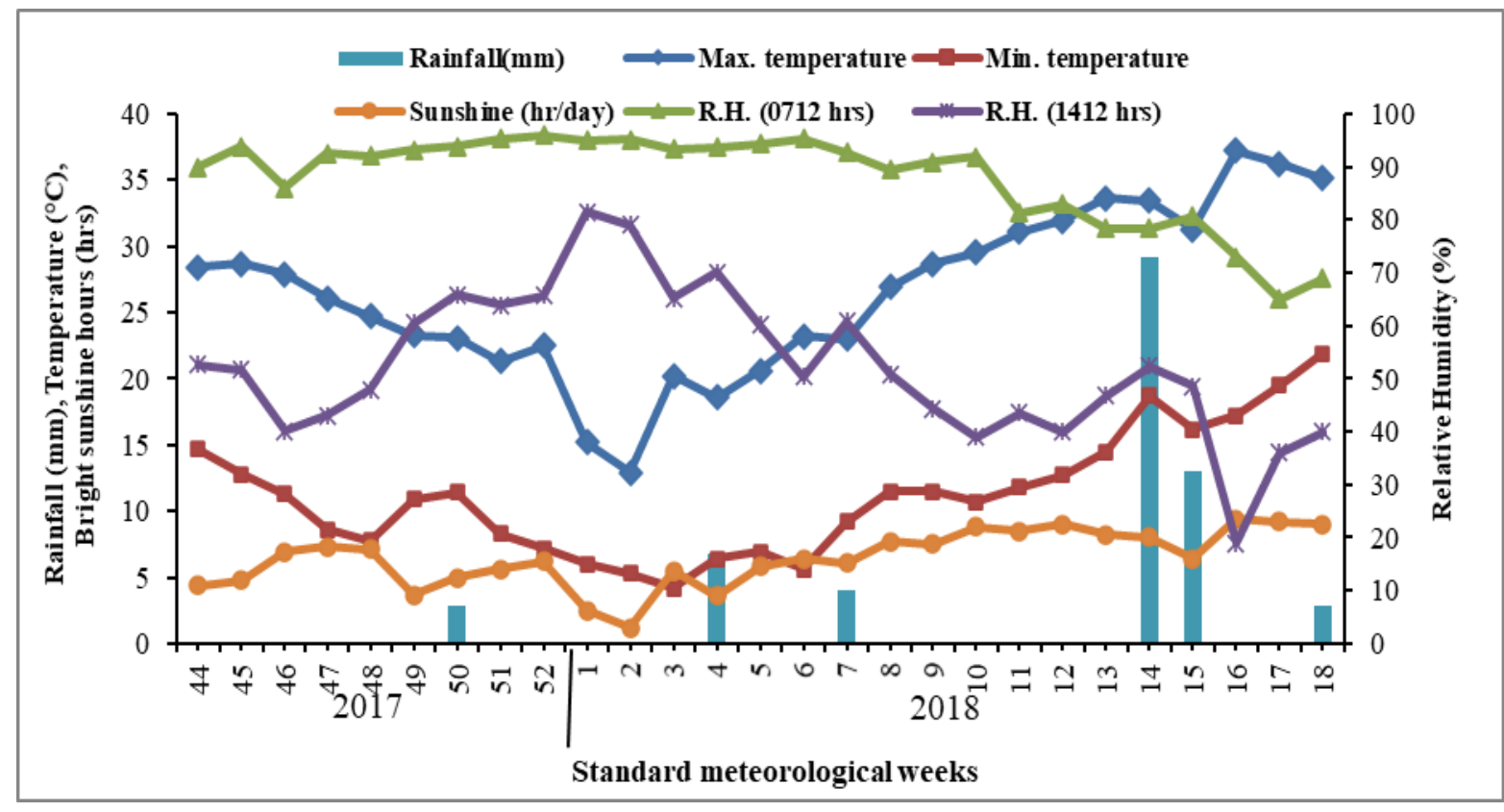

Fig. 1. Weekly data of weather parameters during rabi season (2017-18). (Source: Agromet observatory, GBPUA\&T, Pantnagar,Uttrakhand, India). 


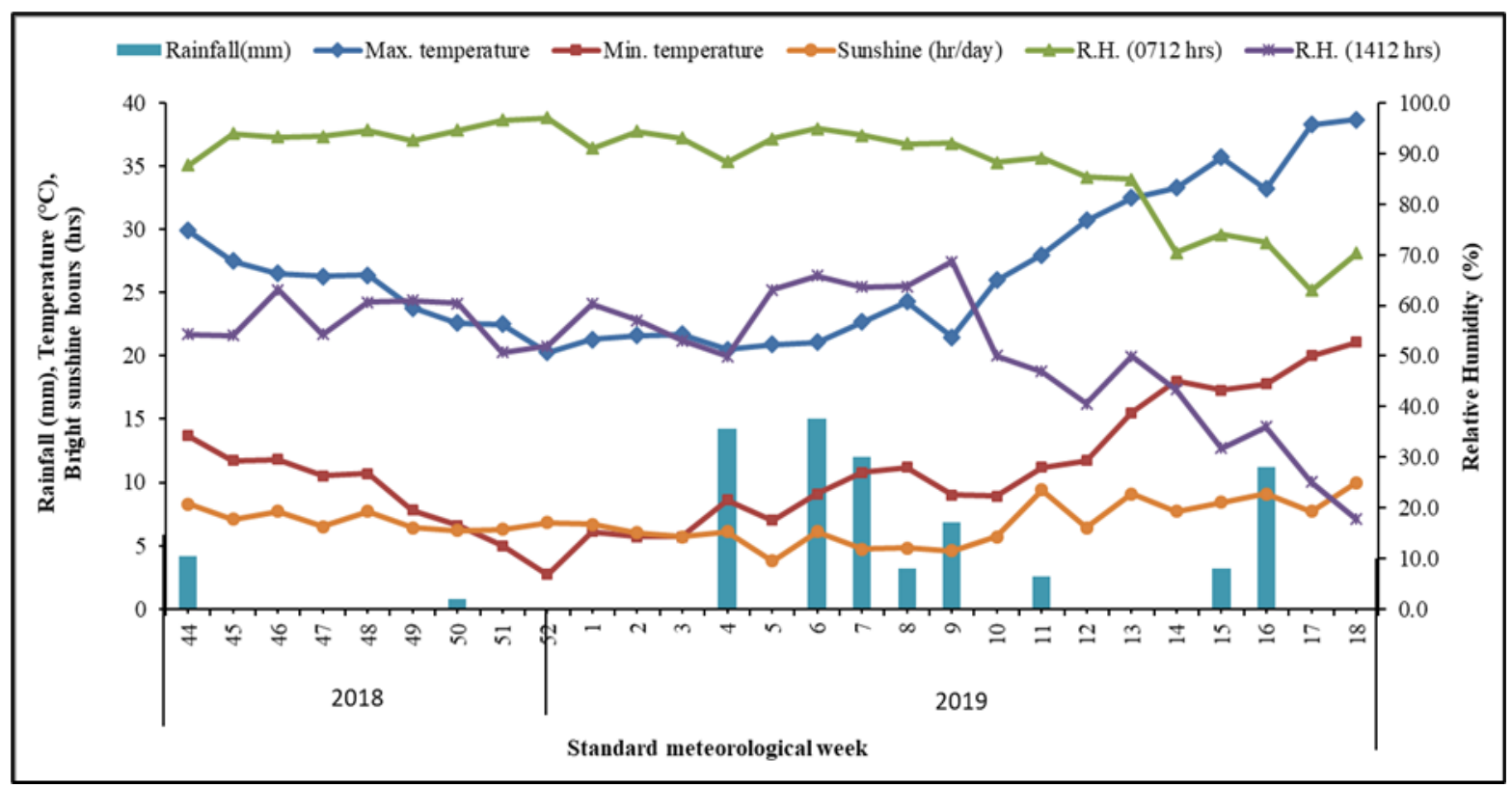

Fig. 2. Weekly data of weather parameters during rabi season (2018-19). (Source: Agromet observatory, GBPUA\&T, Pantnagar,Uttrakhand, India).

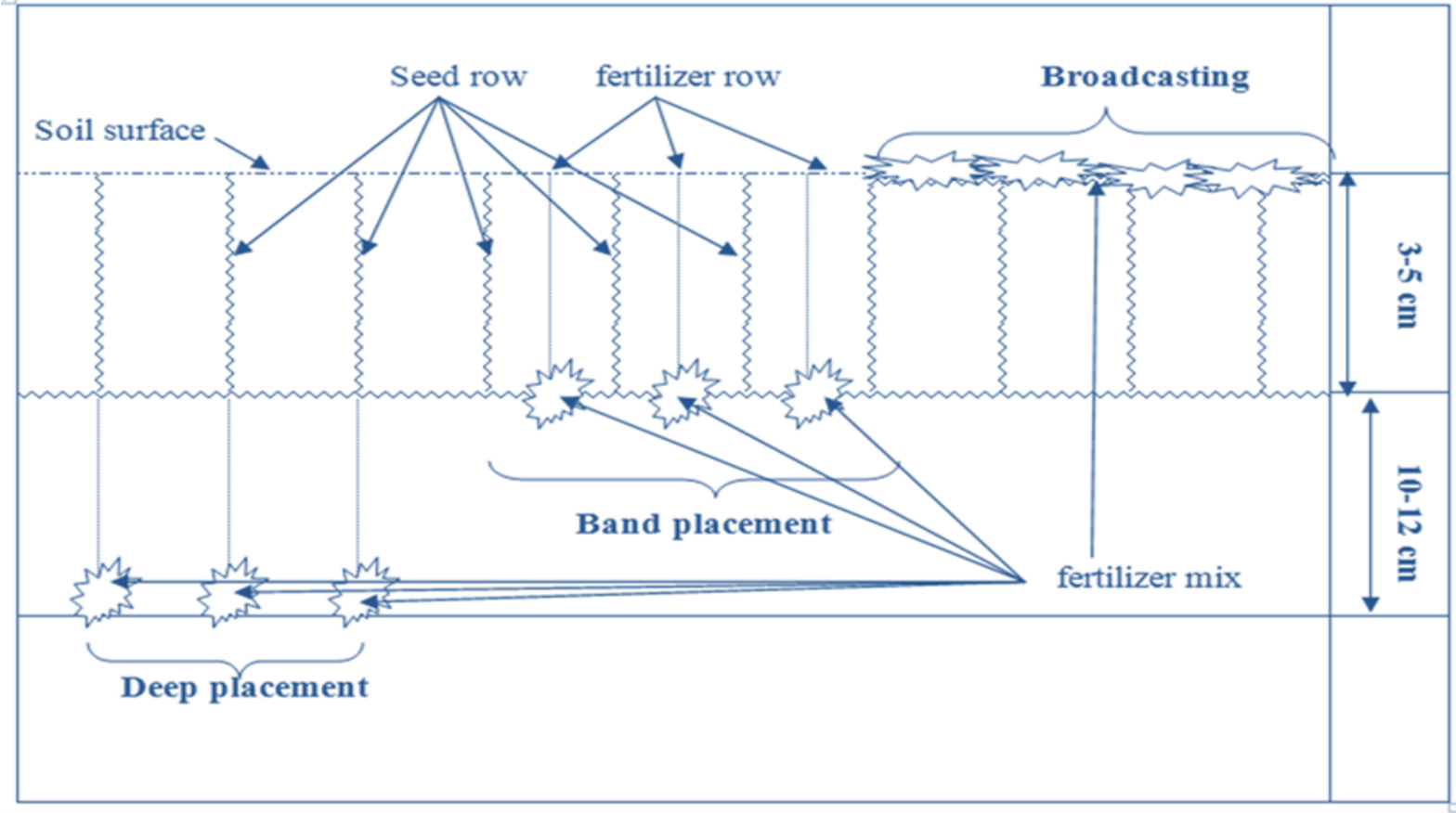

Fig. 3. Targeted view of different fertilizers application methods in experimental plots.

spectively. The magnitude of increase in grain yield by P1 over P2 was higher than P3. However, P3 was found at par with P1 during 2017-18. Whereas, P2 and P3 were found at par during 2018-19. The reasons for higher grain yield in deep placement during both years were attributed due to higher dry matter accumulation, effective tillers $/ \mathrm{m}^{2}$, number of grains/spike and 1000grain weight. This might be attributed due to better utilization of nutrient in the localized supply of nutrients. These findings were supported by the Ali et al. (2012); Chen et al. (2016) and Wu et al. (2017). They reported with use of organic and inorganic fertilizers and biofertilizers that maximum grain yield was observed with fertilizers placement due to high concentration of solute at fertilizer placement sites inhibited nitrification by the osmotic potential of the solutes thus provides long term bioavailability of nutrients. This provided efficient uptake of nutrient and higher grain yield in wheat ( $T$. aestivum L.) by fertilizer placement compared to broadcasting (Rehim et al., 2012). The similar response was also reported in this findings where deep placement of combined fertilizer mix was found more efficient than band placement and surface application. However, differential environmental conditions also favoured the importance of fertilizers placement for efficient utilization of nutrient resources, as shown in 
Table 1. Grain yield ( $\mathrm{t} / \mathrm{ha}$ ) of wheat ( $T$. aestivum $\mathrm{L}$.) as influenced by rhizospheric nutrient management.

\begin{tabular}{lcc}
\hline Treatment & \multicolumn{2}{c}{ Grain yield (t/ha) } \\
\cline { 2 - 3 } & $\mathbf{2 0 1 7 - 1 8}$ & $\mathbf{2 0 1 8 - 1 9}$ \\
\hline Placement methods & & \\
Deep placement (P1) & 5.4 & 5.5 \\
Surface application (P2) & 5.1 & 5.2 \\
Band placement (P3) & 5.3 & 5.3 \\
CD (P=0.05) & 0.2 & 0.2 \\
Nutrient management & & 5.2 \\
100\% RDF (T1) & 5.2 & 5 \\
$75 \%$ RDF (T2) & 4.9 & 5.4 \\
$75 \%$ RDF + VC (T3) & 5.4 & 5.7 \\
$75 \%$ RDF + VC + PSB (T4) & 5.8 & 5.2 \\
$75 \%$ RDF + PM (T5) & 5.1 & 5.4 \\
$75 \%$ RDF + PM + PSB (T6) & 5.4 & 0.3 \\
CD (P=0.05) & 0.3 & \\
Control vs rest & & 3.3 \\
Control & 3.5 & 5.3 \\
Rest & 5.3 & 0.4 \\
CD (P=0.05) & 0.4 & 6.7 \\
C.V. (\%) & 6 & \\
\hline
\end{tabular}

Table 2. Changes in root dry weight and root density in the $0-20 \mathrm{~cm}$ soil profile in wheat ( $T$. aestivum L.).

\begin{tabular}{|c|c|c|c|c|c|c|c|c|}
\hline \multirow{3}{*}{ Treatment } & \multicolumn{4}{|c|}{ Root weight (g/cc) } & \multicolumn{4}{|c|}{ Root weight density (mg/cc) } \\
\hline & \multicolumn{2}{|c|}{$\begin{array}{l}\text { At maximum } \\
\text { tillering stage }\end{array}$} & \multicolumn{2}{|c|}{$\begin{array}{l}\text { At flowering } \\
\text { stage }\end{array}$} & \multicolumn{2}{|c|}{$\begin{array}{l}\text { At maximum } \\
\text { tillering stage }\end{array}$} & \multicolumn{2}{|c|}{ At flowering stage } \\
\hline & 2017-18 & 2018-19 & 2017-18 & 2018-19 & 2017-18 & 2018-19 & 2017-18 & 2018-19 \\
\hline \multicolumn{9}{|l|}{ Placement methods } \\
\hline Deep placement (P1) & 1.52 & 1.73 & 2.17 & 2.69 & 1.29 & 1.47 & 1.84 & 2.29 \\
\hline Surface application (P2) & 1.46 & 1.60 & 1.98 & 2.32 & 1.24 & 1.36 & 1.68 & 1.97 \\
\hline Band placement (P3) & 1.64 & 1.75 & 2.05 & 2.55 & 1.39 & 1.49 & 1.74 & 2.17 \\
\hline$C D(P=0.05)$ & 0.13 & 0.12 & 0.10 & 0.19 & 0.11 & 0.10 & 0.09 & 0.16 \\
\hline \multicolumn{9}{|l|}{ Nutrient management } \\
\hline $100 \%$ RDF (T1) & 1.50 & 1.71 & 2.09 & 2.60 & 1.27 & 1.45 & 1.77 & 2.21 \\
\hline $75 \%$ RDF (T2) & 1.35 & 1.52 & 1.91 & 2.25 & 1.14 & 1.29 & 1.62 & 1.91 \\
\hline $75 \%$ RDF + VC (T3) & 1.61 & 1.71 & 2.12 & 2.50 & 1.36 & 1.45 & 1.80 & 2.13 \\
\hline $75 \%$ RDF + VC + PSB (T4) & 1.63 & 1.77 & 2.17 & 2.73 & 1.39 & 1.51 & 1.84 & 2.32 \\
\hline $75 \%$ RDF + PM (T5) & 1.53 & 1.68 & 2.09 & 2.49 & 1.30 & 1.43 & 1.77 & 2.11 \\
\hline 75\% RDF + PM + PSB (T6) & 1.65 & 1.76 & 2.02 & 2.56 & 1.40 & 1.50 & 1.72 & 2.17 \\
\hline$C D(P=0.05)$ & 0.19 & 0.16 & 0.14 & 0.27 & 0.16 & 0.14 & 0.12 & 0.23 \\
\hline \multicolumn{9}{|l|}{ Control vs rest } \\
\hline Control & 1.00 & 1.40 & 1.68 & 1.99 & 0.85 & 1.19 & 1.42 & 1.69 \\
\hline Rest & 1.54 & 1.69 & 2.07 & 2.52 & 1.31 & 1.44 & 1.75 & 2.14 \\
\hline$C D(P=0.05)$ & 0.23 & 0.21 & 0.18 & 0.34 & 0.20 & 0.18 & 0.15 & 0.29 \\
\hline C.V. (\%) & 12.90 & 10.28 & 7.34 & 11.47 & 12.90 & 10.28 & 7.34 & 11.47 \\
\hline
\end{tabular}

Data in boxes mean the proportions of root weight in soil layer $(0-20 \mathrm{~cm})$.

Fig. 1 and 2.

Nutrient management was significantly influencing the grain yield during 2017-18 and 2018-19. Although, the maximum grain yield (5.8 and $5.7 \mathrm{t} / \mathrm{ha}$ ) was recorded significantly under T4 followed by T6 (5.4 and $5.4 \mathrm{t} /$ ha), T3 (5.4 and $5.4 \mathrm{t} / \mathrm{ha}), \mathrm{T} 1$ (5.2 and $5.2 \mathrm{t} / \mathrm{ha}), \mathrm{T} 5$
(5.1 and 5.2 t/ha) and T2 (4.9 and 5 t/ha) during 201718 and 2018-19, respectively. Whereas, T6, T4, T3 and T1 were found at par with each other. $75 \%$ RDF + poultry manure was also observed at par with $75 \%$ RDF alone and $100 \%$ RDF. It revealed that integration of nutrient helps in better soil environment with respect 
Kumar A. et al. / J. Appl. \& Nat. Sci. 12(4): 511 - 518 (2020)

Table 3. Effect of rhizospheric nutrient management on partial factor productivity in wheat ( $T$. aestivum L.).

\begin{tabular}{|c|c|c|c|c|c|c|}
\hline \multirow[t]{3}{*}{ Treatment } & \multicolumn{6}{|c|}{ Partial factor productivity (kg/kg nutrient applied) } \\
\hline & \multicolumn{2}{|c|}{ Nitrogen } & \multicolumn{2}{|c|}{ Phosphorus } & \multicolumn{2}{|c|}{ Potassium } \\
\hline & 2017-18 & 2018-19 & 2017-18 & 2018-19 & 2017-18 & 2018-19 \\
\hline $\begin{array}{l}\text { Placement methods } \\
\text { Deep placement (P1) }\end{array}$ & 44.8 & 45.1 & 114.1 & 114.9 & 170.1 & 171.2 \\
\hline $\begin{array}{l}\text { Surface application } \\
\text { (P2) }\end{array}$ & 41.8 & 42.4 & 106.4 & 108 & 158.6 & 161 \\
\hline Band placement (P3) & 43.5 & 43.9 & 110.9 & 111.9 & 165.4 & 166.8 \\
\hline $\begin{array}{l}C D(P=0.05) \\
\text { Nutrient management }\end{array}$ & 1.8 & 2 & 4.5 & 5.1 & 6.7 & 7.6 \\
\hline $100 \%$ RDF (T1) & 34.4 & 34.7 & 86.1 & 86.7 & 129.1 & 130.1 \\
\hline $\begin{array}{l}\text { 75\% RDF (T2) } \\
\text { 75\% RDF + VC (T3) }\end{array}$ & $\begin{array}{l}43.4 \\
45.6\end{array}$ & $\begin{array}{l}44.1 \\
46.2\end{array}$ & $\begin{array}{l}108.5 \\
116.4\end{array}$ & $\begin{array}{l}110.2 \\
117.9\end{array}$ & $\begin{array}{l}162.8 \\
173.1\end{array}$ & $\begin{array}{l}165.3 \\
175.4\end{array}$ \\
\hline $\begin{array}{l}75 \% \text { RDF + VC + PSB } \\
\text { (T4) }\end{array}$ & 49 & 48.3 & 125.1 & 123.3 & 186.1 & 183.4 \\
\hline $75 \%$ RDF + PM (T5) & 42.4 & 43.9 & 109.7 & 113.5 & 163.1 & 168.7 \\
\hline $\begin{array}{l}75 \% \text { RDF + PM + PSB } \\
\text { (T6) }\end{array}$ & 45.2 & 45.5 & 117 & 117.8 & 173.9 & 175 \\
\hline $\begin{array}{l}C D(P=0.05) \\
\text { Control vs rest }\end{array}$ & 2.5 & 2.8 & 6.3 & 7.2 & 9.4 & 10.7 \\
\hline Control & 0 & 0 & 0 & 0 & 0 & 0 \\
\hline Rest & 43.3 & 43.8 & 110.5 & 111.6 & 164.7 & 166.3 \\
\hline$C D(P=0.05)$ & 3.1 & 3.5 & 7.9 & 9 & 11.8 & 13.5 \\
\hline C.V. (\%) & 6.3 & 7.1 & 6.3 & 7.1 & 6.3 & 7.1 \\
\hline
\end{tabular}

to moisture and nutrient release, which was evident from better growth and yield attributing characters, particularly the spike number and grain per spike. Optimal nutrition with combined application of chemical fertilizers and organic manures along with rhizobacteria might be play important role in exploiting high yield potential of wheat ( $T$. aestivum) through its favourable effect on nutrient supply and soil biophysical environment (Chesti et al., 2013). Bahadur et al. (2013) reported that the grain yield of wheat $(T$. aestivum ) increased along with increasing total uptake of $\mathrm{N}, \mathrm{P}$ and $\mathrm{K}$ in the plant due to the improvement in the rhizospheric environment. The integration of NPK fertilizers with organic sources significantly increased in plant dry matter accumulation, a number of tillers $/ \mathrm{m}^{2}$, spike length and 1000 -grain weight along with higher grain and straw yield of wheat ( $T$. aestivum ) (Bhoite, 2005). These similar findings curve were also observed in this experiment where $75 \%$ of RDF and vermicompost/ poultry manure with PSB reported higher grain yield and NUE of wheat ( $T$. aestivum L.) than fertilizers alone and other lower-dose combination without PSB.

In case of control vs rest, control plot observed lowest grain yield than other treatments due to low availability of nutrients, reduction in plant biomass production and nutrient utilization. The non-significant interaction effect was recorded on grain yield of wheat ( $T$. aestivum L.) during the year 2017-18 and 2018-19.

Root distribution studies: The data pertaining to root studies of wheat at maximum tillering and flowering stages under different fertilizer placement meth- ods and nutrient management are furnished in Table 2 and Fig. 3.

Root weight (g/cc) and root density (mg/cc): Fertilizer placement methods influenced the root weight of wheat significantly $(p=0.05)$ at maximum tillering and flowering stages during both the years of experimentation. P3 (1.64 and $1.75 \mathrm{~g} / \mathrm{cc}$ ) being at par with P1 (1.52 and $1.73 \mathrm{~g} / \mathrm{cc}$ ) recorded significantly higher root weight over P2 (1.46 and $1.60 \mathrm{~g} / \mathrm{cc}$ ) at maximum tillering stage during the 2017-18 and 2018-19, respectively. However, at flowering stage, P1 (2.17 and $2.69 \mathrm{~g} / \mathrm{cc}$ ) was recorded significantly higher root weight compared to P3 (2.05 and $2.55 \mathrm{~g} / \mathrm{cc}$ ) and P2 (1.98 and $2.69 \mathrm{~g} / \mathrm{cc}$ ) during the 2017-18 and 2018-19, respectively. But, during 2017-18, P3 and P2, and during 2018-19, P1 and P3 were at par with each other. The similar trend was also recorded with root density at maximum tillering stage and flowering stage during 2017-18 and 2018-19. This might be due to various nutrient spatial-temporal environments. It was also notified by Zhang et al., (2010) that The fertilizer banding enriches the narrow zone of root with nutrient which enhanced the $P$ bioavailability, accelerate root proliferation and crop productivity of wheat ( $T$. aestivum $L$.). The root distribution takes place from lower nutrient concentration to nutrient-rich environment for better nutrient utilization in $T$. aestivum crop under localized application of inorganic and organic fertilizers combinations (Shen et al., 2013; Shu et al., 2007). These findings also supported the experimental findings where organic and inorganic fertilizers combination favoured the localized application of fertilizers for improving crop yield and NUE of wheat. 
The localized nutrient supply regulates root development and modifies the physicochemical processes of the rhizospheric environment which influenced the rhizospheric interfaces through physiological and metabolic activities to enhance the nutrient availability of soil and root growth of wheat ( $T$. aestivum L.) (Ma et al., 2013 and Jing et al., 2010).

Nutrient management influenced the root weight significantly at maximum tillering and flowering stages during both the years of experimentation. T4 $(1.63 \mathrm{~g} /$ cc) was recorded the highest root weight at the maximum tillering stage which was followed by T6 $(1.65 \mathrm{~g} /$ $\mathrm{cc})$, T3 (1.61 g/cc), T5 (1.53 g/cc), T1 (1.50 g/cc), and T2 (1.35 g/cc), respectively during 2017-18. However, The T4 $(1.77 \mathrm{~g} / \mathrm{cc})$ was gain significantly maximum root weight followed by T6 $(1.76 \mathrm{~g} / \mathrm{cc}), \mathrm{T} 1(1.71 \mathrm{~g} / \mathrm{cc})$, T3(1.71 g/cc), T5 (1.68 g/cc) and T2 (1.52 g/cc), respectively during 2018-19. This similar trend was also observed in root weight at the flowering stage during 2018-19 and root weight density at maximum tillering and flowering stage during 2017-18 and 2018-19. The better root density under nutrient management might be due to the loose and friable rhizospheric conditions created by the decomposition of organic manure and biological activity which further decreased the root penetration resistance by decreasing the cohesive and massive structure of the soil, particularly in the topsoil. The root growth of wheat increased due to increases in nutrient availability into the rhizospheric soil and crop productivity (Jing et al., 2010).

Absolute control observed the lowest root weight and root weight density at both maximum tillering and flowering stage during the year 2017-18 and 2018-19, respectively. Moreover, Interaction effect did not found significant on both root weight and root weight density of wheat ( $T$. aestivum L.) during the year 2017-18 and 2018-19, respectively.

Nutrient use efficiency: Data pertaining to nutrient use efficiency is given in Table 3. Data revealed that P1 was found to be efficient in improving crop nutrient use efficiency as followed by P3 and P2. Nutrient use efficiency/partial factor productivity (PFP) was recorded highest in $\mathrm{P} 1$ in the case of $\mathrm{N}, \mathrm{P}$ and $\mathrm{K}$ fertilizers use followed P3 and P2, respectively. However, P1 was found at par with $\mathrm{P} 3$ respective to partial factor productivity of $\mathrm{N}, \mathrm{P}$ and $\mathrm{K}$. Among the nutrient management treatments, combined use of $75 \%$ RDF + vermicompost + PSB recorded higher crop nutrient use efficiency and PFP for N, P, K that was followed by the application of other nutrient management options. All these parameters were observed lowest in the application of RDF without supplementation with organic manure and PSB. The efficient management of rhizospheric processes and root system accelerated the efficiency of crop genotypes, microbial interactions, nutrient use efficiency by localized application of fertilizers. It was also observed by Shen et al., (2013) and Cakmakci et al., (2014). Whereas, Zhang et al.,
(2010) and Jiao et al., (2016) recorded that root and root mediated rhizosphere processed modifying the root exudation, and intensified the rhizospheric interactions due to localized fertilizer application with combined use of fertilizer in wheat ( $T$. aestivum L.) crop.

\section{Conclusion}

We found that wheat $T$. aestivum growing in Tarai soil (beni series) was highly responsive to rhizospheric nutrient management. The deep placement and 75\% RDF+ Vermicompost+ PSB treatments resulted in higher grain yield and nutrient use efficiency than surface application due to improved root proliferation and distribution in $>20 \mathrm{~cm}$ depth surface soil than surface application. Since the deep placement offered no significant growth or yield advantages over the band placement, we recommended the fertilizer placement and $75 \%$ RDF + Vermicompost+ PSB application in the soil to hasten the wheat productivity. However, integration of organic and inorganic fertilizers along with biofertilizers proved their efficiency to a reduction in inorganic fertilizer cost because it did not possess significant difference with the application of inorganic fertilizers alone $(100 \%$ RDF) in wheat yield. Experimental results concluded that the rhizospheric nutrient management (fertilizer placement and nutrient management) practices could boost yields of wheat $T$. aestivum in Tarai region Of Uttrakhand state. These results indicated that deep placement of fertilizer was a feasible and practical means of increasing grain yield and nutrient use efficiency of wheat by promoting the growth of deep roots in Tarai regions of Uttarakhand.

\section{Conflict of interest}

The authors declare that they have no conflict of interest.

\section{REFERENCES}

1. Aggrawal, S.B., Singh, A. and Dwivedi, D. (2003). Effect of vermicompost, farm yard manure and chemical fertilizers on growth and yield of Wheat (Triticum Aestivum L.). Plant Archives, 3(1): 9-14. https://www.researchgate.net/ publication/230701571

2. Ali, A., Ayesha, Hameed, S., Imran, A., Iqbal, M., Iqbal, J., et al., (2012). Functional characterization of a soybean growth stimulator Bradyrhizobium sp. strain SR-6 showing acylhomoserine lactone production. FEMS Microbiol Ecol, http://www.ncbi.nlm.nih.gov/pubmed/ 27242370

3. Bahadur, L., Tiwari, D. D., Mishra, J. and Gupta, B. R. (2013). Nutrient management in rice-wheat sequence under sodic soil. Journal of the Indian Society of Soil Science, 61(4): 341-346. https://www.researchgate.net/ publication/236594021

4. Bhatt, B., Chandra, R., Ram, S. and Pareek, N. (2016). Long-term effects of fertilization and manuring on productivity and soil biological properties under rice (Oryza sativa)-wheat (Triticum aestivum) sequence in Mollisols. Archives of Agronomy and Soil Science, 1-14. https://doi.org/10.1080/03650340.2015.1125471

5. Bhoite, S. V. (2005). Integrated nutrient management in 
basmati rice (Oryza sativa)-wheat (Triticum aestivum) cropping system. Indian Journal of Agronomy, 50(2): 98101. https://www.researchgate.net/publication/290361869

6. Cakmakci R, Turan M, Gulluce M, Sahin F. (2014). Rhizobacteria for reduced fertilizer inputs in wheat (Triticum aestivum spp. vulgare) and barley (Hordeum vulgare) on Aridisols in Turkey. International Journal of Plant Production, 8(2):163-182. https://www.researchgate.net/publicat ion/282650729

7. Chen, Z., Wang, H., Liu, X., Liu, Y., Gao, S. and Zhou, J. (2016). The effect of $N$ fertilizer placement on the fate of urea- $15 \mathrm{~N}$ and yield of winter wheat in southeast China. PLoS One, 11(4). doi:10.1371/journal.pone.0153701

8. Chesti, M.H., Kohli, A. and Sharma, A.K. (2013). Effect of integrated nutrient management on yield of and nutrient uptake by wheat (Triticum aestivum) and soil properties under intermediate zone of Jammu and Kashmir. Journal of the Indian Society of Soil Science, 61(1): 1-6. https:// www.researchgate.net/publication/287088256

9. Deshpande, S.B., Fehrenbacher, J.B. and Beaureren, A.N. (1971). Study of mollisols of tarai region of Uttar Pradesh, Northern India, Mineralogy Geoderma, 6:179-193. DOI: 10.22271/chemi.2020.v8.i3j.9305

10.Fan, M., J. Shen, L. Yuan, R. Jiang, X. Chen, W.J. Davies, F. Zhang, (2012). Improving crop productivity and resource use efficiency to ensure food security and environmental quality in China. Journal of Experimental Botany, 63 (1): 13-24. DOI: 10.1093/jxb/err248

11.FAO, (2017). OECD-FAO Agricultural Outlook, OECD Agriculture statistics (database).

12.Foley, J.A., Ramankutty, N., Brauman, K.A., Cassidy, E.S., Gerber, J.S. and Johnston, M. (2011). Solutions for a cultivated planet, Nature, 478(7369): 337-342. https:// doi.org/10.1038/nature10452

13.GOI, (2016). Agricultural Statistics at a Glance. Directorate of Economics and Statistics. Department of Agriculture and Cooperation, Ministry of Agriculture. http// dacnet.nic.in.

14.Jiao, X., Lyu, Y., Wu, X., Li, H., Cheng, L., Zhang, C., \& Zhang, F. (2016). Grain production versus resource and environmental costs: towards increasing sustainability of nutrient use in China. Journal of experimental botany, 67 (17): 4935-4949. https://doi.org/10.1093/jxb/erw282

15.Jing, J., Rui, Y., Zhang, F., Rengel, Z., Shen, J., (2010). Localized application of phosphorus and ammonium improves growth of maize seedlings by stimulating root proliferation and rhizosphere acidification. Field Crop Research, 119: 355-364. https://doi.org/10.1016/ j.fcr.2010.08.005

16.Kumar, A., Singh V.P., Kumar R., Pandey D.S., (2019). Integrated nutrient management: An approach to boost sustainable wheat production. International Journal of Chemical Studies. 7(3): 4479-4482.

17.Kumar, P., Yadava, R.K., Gollen, B., Kumar, S., Verma, R.K., Yadav, S., (2011). Nutritional contents and medicinal properties of wheat: A review, Life Sciences and Medicine Research, 22: 1-10. https://www.researchgate.net/ publication/280920597

18.Marschner, P. (2012). Mineral nutrition of higher plants, 3rd edn. London: Academic Press

19.Mengual, C., Schoebitz M., Azcon R., Roldan A., (2014). Microbial inoculants and organic amendments improves plant establishment and soil rehabilition under semiarid conditions, Journal of environmental management, 134:17. https://doi.org/10.1016/j.jenvman.2014.01.008

20.Mi, G.H., Chen F.J., Wu Q.P., Lai N.W., Yuan L.X. and Zhang F.S. (2010). Ideotype root architecture for efficient nitrogen acquisition by maize in intensive cropping systems. Science India Life Sciences. 53:1369-1373. https:// doi.org/10.1007/s11427-010-4097-y

21.Nkebiwe, P. M., Weinmann, M., Bar-Tal, A. and Müller, T. (2016). Fertilizer placement to improve crop nutrient acquisition and yield: A review and meta-analysis. Field Crops Research, 196:389-401. DOI: 10.1016/j.fcr.201 6.07.018

22.Pullicinoa, D.S., Massaccesia, L., Dixonb, L. Bolb, R. and Gigliottia, G. (2009). Organic matterdynamics in a compost-amended anthropogenic landfill capping-soil. EuropeanJournal Soil Science, 61: 35-47. https:/l doi.org/10.1111/j.1365-2389.2009.01198.x

23.Rangaswamy, R., (2005). A text book of agricultural statistics, New age international (P) limited, New delhi. Book Chapter

24.Rehim A, Farooq M, Ahmad F, Hussain M. (2012). Band placement of phosphorus improves the phosphorus use efficiency and wheat productivity under different irrigation regimes. International Journal of Agriculture and Biology 14: 727-733. https://www.researchgate.net/publication/271271 319

25.Shen, J. B., Li, C. J., Mi, G. H., Li, L., Yuan, L. X., Jiang, R. F., et al. (2013). Maximizing root/rhizosphere efficiency to improve crop productivity and nutrient use efficiency in intensive agriculture of China. Journal of Experimental Botany. 64: 1181-1192. doi: 10.1093/jxb/ers342

26.Shu, L., Shen J., Rengel Z., Tang C., Zhang F., \& Cawthray G.R., (2007). Formation of cluster roots and citrate exudation by lipinus albus in response to localized application of different phosphorus sources. Plant science, 172(5):1017-1024. https://doi.org/10.1016/j.plantsci.200 7.02 .006

27.Weber, E., Koller, W.-D., Graeff, S., Hermann, W., Merkt, N. and Claupein, W. (2008). Impact of different nitrogen fertilizers and an additional sulfur supply on grain yield, quality, and the potential of acrylamide formation in winter wheat. Journal of Plant Nutrition and Soil Science, 171(4): 643-655. https://doi.org/10.1002/jpln.200700229

28.Wu, M., Li, G., Li, W., Liu, J., Liu, M., Jiang, C. and Li, Z. (2017). Nitrogen fertilizer deep placement for increased grain yield and nitrogen recovery efficiency in rice grown in subtropical China. Frontiers in plant science, 8: 12-27. https://doi.org/10.3389/fpls.2017.01227

29.Zhang, F.S., Shen J.B., Zhang J.L., Zuo Y.M., Li L. and Chen X.P. (2010). Rhizosphere processes and management for improving nutrient use efficiency and crop productivity: implications for India. In: Sparks D.L., San Diego: Academic Press. ed, Advances in agronomy, 107:1-32. doi:10.1093/jxb/ers342 